\title{
AN OVERVIEW OF AMPHIBIAN FAUNA OF PUNE DISTRICT WITH SPECIAL REFERENCE TO THEIR STATUS IN AND AROUND PUNE CITY
}

\author{
A.D. Padhye ${ }^{1}$, Mukul Mahabaleshwarkar ${ }^{1}$ and H.V. Ghate ${ }^{2}$ \\ ${ }^{1}$ Department of Zoology, Abasaheb Garware College, Pune, Maharashtra 411004, India. \\ ${ }^{2}$ Department of Zoology, Modern College, Shivajinagar, Pune, Maharashtra 411005, India.
}

\begin{abstract}
For the last 30 years, Pune has been a center of industrialization and concomitant urbanization. As a result the city is rapidly growing, in size as well as in population, at the cost of its environment. This has severely impacted the flora and fauna of the city and its outskirts. We have been studying the impact of urbanization on amphibians for the last few years. Our studies reveal that there has been a loss of one-third of amphibian species from the city area in the last 25 years, mainly due to habitat destruction. The situation is similar in other townships throughout Pune District.
\end{abstract}

\section{Keywords \\ Amphibia, status, Pune City, Pune District, urbanisation}

\section{Introduction}

Pune District $\left(17^{0} 54^{\prime}-19^{\circ} 21^{\prime} \mathrm{N}\right.$ and $\left.73^{\circ} 18^{\prime}-75^{\circ} 13^{\prime} \mathrm{E}\right)$ has the Western Ghats on its western border and thus the western half of the District lies in the rain shadow of Sahyadri Mountains. A very narrow strip on western border of Pune District forms the crest line of the Western Ghats. This strip shows heavy rainfall. There are many small and big dams in this narrow strip. The altitude ranges from $600 \mathrm{~m}$ to $1200 \mathrm{~m}$. This part of the district contains lakes, perennial streams, rain forests, grass lands, hill slopes and paddy fields. The high diversity of habitats is responsible for the amphibian diversity in this part of the district.

The eastern half of the district shows very scanty rainfall. The altitude ranges between $300 \mathrm{~m}$ to $400 \mathrm{~m}$. There are more semiarid planes and scrubs, some of which were used for urbanization and industrialization in last few years. The amphibian diversity of this part probably is not as rich as that of the western part, however more surveys are essential.
Pune City $\left(18^{\circ} 31^{\prime} \mathrm{N}\right.$ and $\left.73^{\circ} 51^{\prime} \mathrm{E}\right)$, one of the most urbanized areas in Maharashtra state, is situated on Deccan Plateau almost on its western margin and lies on the leeward side of the Western Ghats. The narrow strip of moderate rainfall, in which the city is located, is known as rain shadow of Sahyadri - Western Ghats. It is the middle part of the district. The altitude ranges between $400 \mathrm{~m}$ to $600 \mathrm{~m}$. It shows hill-ranges and scattered peaks having higher altitudes (up to $1400 \mathrm{~m}$ ). Rainfall is spread over five months from June to October with a peak during July. This part of the district shows higher amphibian diversity as it has both semitropical as well as semiarid areas.

The city is situated in the basin of the River Bhima. Two main rivers, Mula and Mutha, run through the City and finally meet River Bhima jointly (Sawant, 1972). It is 54km from the crest line of Sahyadri and around $110 \mathrm{~km}$ from the sea. It is located in tropics with monsoon - rainy summer and dry winter. The climate is moderate throughout the year in and around Pune (between $15^{\circ} \mathrm{C}$ to $30^{\circ} \mathrm{C}$ with minimum temperature being $4^{\circ} \mathrm{C}$ in DecemberJanuary and maximum temperature around $40^{\circ} \mathrm{C}$ in April- May). Average rainfall is around $715 \mathrm{~mm}$ per year because Pune lies in rain shadow of Sahyadri. Various hills and hillocks surround the main parts of the city. Some hills were used for afforestation programs by the forest department, private housing societies and some NGOs. These hills and many other areas, especially on the outskirts of the city, are still green with vegetation. This plantation is of species like Gliricidia, Australian Acacia, Eucalyptus and some other exotic trees, along with some native vegetation that includes dry and moist deciduous as well as some evergreen species.

There is a fear of amphibian declines around the world; in fact severe declines in populations of amphibia have been noted in many parts of the world (Cooke \& Ferguson, 1976; Gupta , 1998; Houlahan et al., 2000). In some cases amphibian declines have been obsevred in areas totally free from any human interference (Lips, 1998; Matton 2000). 




Figure 1. Amphibian sampling sites in Pune District

In the last few years, urbanization and industrialization have been major threats causing habitat destruction on a very large scale. This has ultimately resulted in amphibian population declines in the affected areas of Pune District. A survey was conducted since June 1997 in the entire western part of Pune District and a few places in the eastern part of the district (Fig. 1) to determine if declines have taken place.

As a result of our survey, we have prepared checklists of amphibians both for Pune District as well as Pune City. It is based on personal field observations; study of specimens collected by different field workers and previously published records.

\section{Methodology}

All possible places where amphibians were known to occur in and around Pune City were surveyed. These sites were selected on the basis of previous published literature (Paranjape \& Mulherkar, 1979). These surveys were carried out during the rainy season (late May to late October) of the year 2000 and the presence of various species of frogs was noted either on the basis of actual sighting, presence of egg clutches (for some species) or their calls. A site-wise distribution table was prepared for Pune City (Table 1). Various places in Pune District (randomly selected, mainly in Western Ghats) were also visited during the last three years (Fig. 1).

For those species whose identification in the field was difficult, the specimens were collected and identified in the lab with the help of available identification keys (Boulenger, 1890, 1920; Daniel 
1963a,b, 1975; Daniel \& Sekar, 1989), and were released back into their habitat. However some representative specimens were fixed in buffered formalin, preserved in 5\% glycerol in rectified spirit and then sent to experts for identification or confirmation.

During these visits various other ecological factors like abundance and threat factors such as human interference (cloth washing, vehicle washing, construction activities, garbage dumping, etc.) and pollution, were also noted. Abundance was noted on visual or auditory basis only and no quantitative studies were done.

\section{Observations and Discussion}

\section{Status of amphibians in Pune District}

As per the checklist presented in this paper (Table 2), the amphibian fauna of Pune District comprises of 31 species out of 43 species known from the State (Padhye \& Ghate, 2002) (Fig. 2).

Yazdani and Mahabal (1976) reported 11 different species of amphibians from Pune District (mainly Pune City and surrounding areas). Out of these 11, only eight were actually found in Pune City limits (as per unpublished locality records of WRS-ZSI Pune). With an addition of Philautus bombayensis (Paranjape \& Mulherkar, 1979), the list was updated to 12 species from Pune District (9 from Pune City). Their survey was also restricted to Pune City and its outskirts. Ghate and Padhye (1996) further updated the list to 16 species from Pune District (10 from Pune City), by adding Tomopterna sp. (Kothrud, Pune), Nyctibatrachus humayuni (Bhimashankar), Polypedates maculatus (Lonavla) and Rana malabarica (Pirangut and Bhimashankar). The species Rana limnocharis var. syhadrensis, reported by Paranjape and Mulherkar, (1979) is now treated as a distinct species. Therefore according to all these previous records the tally of species from Pune District goes to 17 and that from Pune City goes to 11. Tomopterna sp., which was an addition to Pune City list (Ghate \& Padhye, 1996), was thought to be rolandii. However, later it was found to be a variation of T. breviceps (now Sphaerotheca breviceps), thus keeping the city species tally to 10 and district tally to 16 . However, the number of species that were found in and around Pune City remains 13 .

Habitat destruction in Pune District has deprived various amphibians of their feeding, breeding and hiding places. For example, a new industrial estate was established in Pirangut, an area near the City, where Rana malabarica as well as Sphaerotheca sp. were very commonly found earlier. Loss of paddy fields, which constitute a major breeding ground for Rana malabarica, has wiped out almost entire populations from the area. Construction of a new ring road, a by-pass and an express highway on the outskirts of the City has caused large-scale amphibian habitat destruction. These new highways constructed to reduce traffic congestion in the City pass through remaining

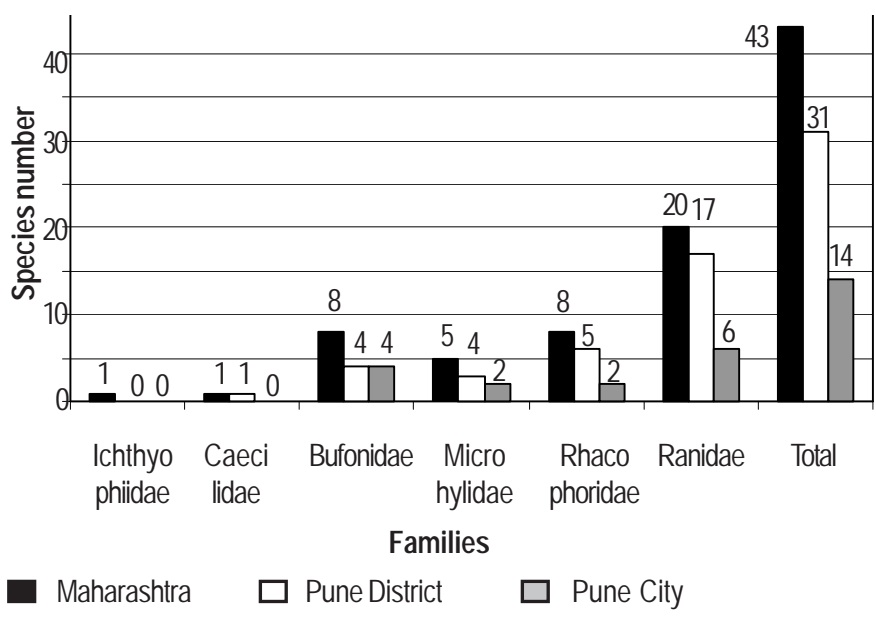

Figure 2. Family-wise distribution of amphibians.

forest areas, paddy fields and grasslands. Habitat quality surrounding these altered areas and roads is degraded due to drastic modification of soil and leveling or filling up of rainwater pools. At some places new highways constructed to enhance the road network pass through the sacred groves, destroying valuable forests. All these changes have drastically affected the amphibian populations and diversity. A sports-city establishment at Balewadi has also caused habitat destruction on a large-scale. Situations are similar in other townships in the entire District.

\section{Status of amphibians in Pune City}

Locality-wise distribution as well as the population status of amphibian species in and around Pune City is given in Table 1, and, Table 2 lists the species in Pune District and City.

Surveying the old city limits now suggests that 9 of the 13 species are not found in the localities mentioned by earlier



Figure 3. Comparative status of amphibians in Pune City. 





workers (Yazdani \& Mahabal, 1976) (see Table 1). Our current survey suggests that five of the 13 species are not found even in the extended city, which has included the peripheral villages since 1976. The missing species are: Bufo stomaticus, $B$. parietalis, B. microtympanum, Euphylctis hexadactylus and Philatus bombayensis. However, during this survey, an additional species (Polypedates maculatus) was observed from the extended city area (now making the city total 14). This additional species, presently found in the newer are as under the current city limits, suggests that it could have gone locally extinct within the Pune City limits before Yazdani and Mahabal's (1976) work. This species must be monitored in future for a better understanding of human influences on local extinctions.

There is thus a loss of around 33\% of amphibian species from these areas (Fig. 3) during the last 25 years (i.e. since Yazdani \& Mahabal, 1976). These species may be found elsewhere within Pune District. The loss is chiefly due to habitat destruction and deforestation, as the species lost are inhabitants of (a) perennial waterbodies, (b) paddy fields, (c) semiarid wasteland areas, and, (d) forests. Other factors like road kills or diseases may not have contributed to this loss, although no systematic work is done on the latter.

Some species show a great adaptability to urbanization and other changes in their natural habitats, Bufo melanostictus being an ideal example (observed feeding on insects under streetlights). They were found to feed on cockroaches and use garden tanks or lotus ponds for breeding. Due to this ability, B. melanostictus is very commonly observed even in the heart of Pune City. Along with B. melanostictus, Euphylctis cyanophlyctis and Limnonectes syhadrensis also seem to have adapted to changes in their natural habitats (they were found to be common at most localities during our survey (see Table 1)). This kind of adaptability is probably not present among the species, which are now rare or absent. It appears that a few species like Uperedon globulosus, Polypedates maculatus and Philautus bombayensis are very sensitive to changes occuring due to urbanisation and industrialization. Due to various threats these species are on the verge of local extinction.

During the past 50 years, Pune has been the centre of industrialization. In fact, it is the second largest industrialized City of Maharashtra State. Concomitant with industrialization, there has been a rapid growth in population in and around Pune City. The net result is urbanization at the cost of deforestation on a large scale. Even the hills and hillocks around the City are now occupied by slum dwellers or private housing societies, and are being excavated for constructing tall buildings.

This growth of the City has been especially rapid since 1970 . One of the authors, H.V.G., has been collecting amphibian eggs for various experiments as well as for the study of natural history, since about 1973. The various areas from where eggs were regularly observed were: Pashan, Kirkee, University campus, Vitthalwadi and many other areas along the banks of Mutha River right up to Khadakwasla Dam, Hingne, Kothrud, Hadapsar, Yerawda, Pune - Nagar Road and adjacent areas. Steadily over a period of about 25 years, we have observed habitat destruction within these areas. Over $70 \%$ of the area, which was once available as habitat for amphibians, is now occupied either by industries, housing societies or slums. There has been wanton destruction of the vegetation covering the areas adjacent to the industries and slums. Moreover, with the City limits getting extended day by day conversion of farms, grasslands, paddy fields and other rural landscapes to human habitations, highways, industrial areas, etc. are a common feature.

In a previous paper we have already highlighted the effects of urbanization on amphibian species in and around Pune (Ghate \& Padhye, 1996). Before that Paranjape and Mulherkar (1979) had also stated that the populations of certain frogs were disappearing due to habitat destruction. Places like Warje, Kothrud, Hingne, Dhayri, Parvati foot hills, Dhankawdi, Katraj, Kondhwa, Nagar Road, Alandi Road, Pashan, etc., in and around Pune City, were once haven for anurans. These now hold only small fragmented populations. Any major calamity, like scanty or irregular rainfall, can totally wipe out such fragmented populations. Construction of low level roads along the sides of riverbed has destroyed breeding sites on a large scale. Recently (while the finalization of this manuscript was in progress), the Municipal Corporation started filling up nullahs and old canals flowing through the City by placing pipelines to drain water; also a road has been constructed on a canal. This will effectively eliminate the last habitats and breeding sites left for frogs in the City.

Habitat destruction due to pollution of breeding ponds is another threat to amphibian population in the cities. Many streams, nullahs, water-filled stone quarries and rivers are polluted with domestic and industrial wastes and the problems due to pollution are discussed in detail in our earlier paper (Ghate \& Padhye, 1996).

The situation appears to be the same for all major townships and cities, in the State where industrial and urban centers are being established. Want of hard data on development activities resulting in amphibian declines has created a problem regarding their conservation (Daniels, 1991). Similar situations however exist in other parts of India -- habitat destruction in the Western Ghats (Daniels, 1991), and destruction of habitat of Himalayan Newt Tylototriton verrucosus in the northern states (Shreshtha, 1989) being only two of the innumerable examples.

Moreover, introduction of exotic fishes like Gambusia affinis and Tilapia (Oreochromis mossambicus) in stone quarries, 


\section{Table 2. Checklist of amphibia of Pune District and City (compiled data).}

\begin{tabular}{|c|c|}
\hline \multicolumn{2}{|l|}{$\begin{array}{l}\text { Gymnophiona } \\
\text { Caeciliaidae }\end{array}$} \\
\hline \multicolumn{2}{|l|}{$\begin{array}{l}\text { Anura } \\
\text { Bufonidae } \\
\text { 2) Bufo melanostictus Schneider PC }\end{array}$} \\
\hline 3) Bufo microtympanum Boulenger! PC & Vetal Tekadi \& Bhosari \\
\hline 4) Bufo parietalis Boulenger ! PC & Katraj \& Wagholi \\
\hline 5) Bufo stomaticus Lutken ${ }^{\mathrm{PC}}$ & $\begin{array}{l}\text { Ferguson College, Pune } \\
\text { University \& Chakan }\end{array}$ \\
\hline \multicolumn{2}{|l|}{$\begin{array}{l}\text { Microhylidae } \\
\text { 6) Microhyla ornata (Duméril \& Bibron) }{ }^{\mathrm{PC}}\end{array}$} \\
\hline 7) Ramanella montana (Jerdon) & Tamhini-Mulshi \\
\hline 8) Uperodon globulosus (Günther) $\mathrm{PC} \$$ & Pashan \& Jambhe \\
\hline \multicolumn{2}{|c|}{$\begin{array}{l}\text { Ranidae } \\
\text { 9) Euphlyctis cyanophlyctis [Rana cyanophlyctis Schneider] }\end{array}$} \\
\hline \multicolumn{2}{|c|}{ 10) Euphlyctis hexadactylus [Rana hexadactyla Lesson] ! Pc } \\
\hline \multicolumn{2}{|c|}{ 11) Hoplobatrachus crassus [Rana crassa Jerdon] ** ? Tamhini-Mulshi } \\
\hline \multicolumn{2}{|c|}{ 12) Hoplobatrachus tigerinus [Rana tigerina Daudin] ${ }^{\mathrm{PC}}$} \\
\hline \multicolumn{2}{|c|}{$\begin{array}{r}\text { 13) Indirana beddomei [Rana beddomei (Günther)] Tamhini-Mulshi, } \\
\text { Lonavla \& Bhimashankar }\end{array}$} \\
\hline 14) Indirana leitheii [Rana leitheii Boulenger] & $\begin{array}{l}\text { Sinhagad, Rajgad \& } \\
\text { Bhimashankar }\end{array}$ \\
\hline \multicolumn{2}{|c|}{$\begin{array}{c}\text { 15) Indirana phrynoderma [Rana phrynoderma Boulenger] }{ }^{*} \\
\text { Mulshi }\end{array}$} \\
\hline 16) Nyctibatrachus humayuni Bhaduri and Kri & $\begin{array}{l}\text { ipalani Lonavla \& } \\
\text { Bhimashankar }\end{array}$ \\
\hline 17) Nyctibatrachus major Boulenger * & Dongarwadi-Mulshi \& Lonavla \\
\hline 18) Limnonectes keralensis [Rana keralensis & s Dubois] * Tamhini-Mulshi \\
\hline
\end{tabular}

nullahs, as well as rivers have resulted in declines in amphibian population (Ghate \& Padhye, 1996). Gambusia affinis, we have observed, consumes tadpoles as well as eggs of Microhyla ornata. In such places microhylids have suffered the most while ranids and bufonids continue to breed. This is the case of two water bodies within the Pune University campus (Ghate \& Padhye, 1988). Gambusia and Tilapia have been introduced in rivers Mula and Mutha. Since the shallow pools and ditches in the riverbed support a good population of Hoplobatrachus tigerinus, Euphlyctis cyanophlyctis as well as Limnonectes syhadrensis, it is necessary to study the long-term effects of this introduction as well. Knowing the voracious feeding habits of Tilapia, it is likely to affect amphibian breeding in the future. Dasgupta (1990) reported that introduction of carps and other
19) Limnonectes limnocharis [Rana limnocharis Gravenhorst] ${ }^{\mathrm{PC}}$

20) Limnonectes nilagirica [Rana nilagarica Jerdon] * Tamhini-Mulshi

21) Limnonectes rufescens [Tomopterna rufescens (Jerdon)] TamhiniMulshi

22) Limnonectes syhadrensis [Rana syhadrensis Annandale] ${ }^{\mathrm{PC} @}$

23) Rana malabarica Tschudi

24) Sphaerotheca dobsonii [Tomopterna dobsonii (Boulenger)]* TamhiniMulshi \& Lonavla

25) Sphaerotheca breviceps [Tomopterna breviceps (Schneider)] ${ }^{\mathrm{PC}}$ Kothrud, Parvati, Alandi \& Tamhini-Mulshi

Rhacophoridae

26) Philautus bombayensis (Annandale) PC Parvati, Vitthalwadi, SInhagad, Lonavla \& Tamhini-Mulshi

27) Philautus leucorhinus (Lichtenstein and Martens) Tamhini-Mulshi

28) Philautus sp. (Closer to glandulosus) Tamhini-Mulshi

29) Philautus sp. (Closer to bombayensis) Tamhini-Mulshi

30) Polypedates maculatus (Gray) ${ }^{\mathrm{PC}+} \quad$ Balewadi, Lonavla, Bhimashankar \& Tamhini-Mulshi

31) Polypedates sp. (different from maculatus) Tamhini-Mulshi

' Authors have not observed these species at any locality within Pune District. * Species reported for the first time from Pune District

* Species reported for the first time from Pune District but their identification is yet to be confirmed.

Scientific names according to Das and Dutta (1998), and Vences et al. (2000). Old names are given in square brackets.

${ }^{\mathrm{PC}}$ Species occuring in Pune City.

\$Tadpoles of Uperodon globulosus were collected from a single locality. However the adults could not be located within current City limits.

${ }^{\circledR}$ cited as Rana limnocharis var. syhadrensis by Paranjape and Mulherkar (1979).

${ }^{+}$Recent addition to the species list from Pune

fishes is a threat to survival of the Himalayan Newt Tylototriton verrucosus.

On the flip side, in the last few years, some hills around Pune City have become green again. This is due to efforts of the forest department, some private housing societies, some temple trusts as well as some non-government organizations. Militaryoccupied hills and scrublands still maintain their near natural status despite human pressures. However, special efforts are essential to re-establish lost amphibian species in these areas.

A definite plan to re-introduce lost species, protection and provision of habitats and breeding sites free from human interference must be evolved to protect amphibians of Pune 
City. In this regard, concerned NGOs or the forest department should take the lead to construct breeding ponds, remove introduced invasives as well as establish an amphibian park similar to a snake park. Such a step will also help in raising public awareness among the city dwellers.

Special International Committees and Task Forces have been established in different parts of the world to understand the reasons for declining amphibian populations. Special measures to conserve amphibians have been initiated all over the world [see Frog Log, Newsletter of Declining Amphibian Population Task Force (DAPTF) being published quarterly for last 8 years and references therein]. Efforts are being made in India as well (Molur \& Walker, 1998) and we hope that the situation will improve.

\section{Acknowledgements}

We are thankful to our friends and students for their valuable help. We thank Ashok Captain, Krushnamegh Kunte, Sanjay Thakur and Vivek Gour-Broome for bringing frog specimens or photographs from different areas. This helped us in updating the list. We are thankful to our students Mandar Paingankar, Nilesh Dahanukar, Rupesh Raut, Rahul Marathe and Sachin Ranade for field work. We are thankful to Dr. S.K. Dutta (Utkal University, Bhubaneswar), Dr. S.K. Chanda (ZSI, Calcutta) and Dr. M.S. Ravichandran (SRS, ZSI - Chennai) for help in identification of some of the specimens. We are also thankful to the Officer-in-charge, WRS, ZSI, Pune for providing unpublished locality records.

H.V.G. is thankful to Principal Modern College and A.D.P. is thankful to Head of the Zoology Department, and the Principal, Abasaheb Garware College for provision of infrastructural facilities. Part of this project was done as a part of the Western Ghat Biodiversity Monitoring Project funded by the Department of Biotechnology, for which we are thankful to the concerned authorities. Lastly, we are thankful to Prof. Dr. Madhav Gadgil for giving us an opportunity to work on this project.

\section{References}

Boulenger, G.A. (1890). Fauna of British India including Ceylon and Burma: Reptilia and Batrachia. Taylor and Francis, London.

Boulenger, G.A. (1920). A monograph of the south Asian, Papuan, Melanesian and Australian frogs of the genus Rana. Records of Indian Museum 20: 1-226.

Cooke, A.S. and P.F. Ferguson (1976). Changes in status of the frog (Rana temporaria) and the toad (Bufo bufo) on part of the East Anglian Fenland in Britain. Biological Conservation 9: 191-198.

Daniel, J.C. (1963a). Field guide to the amphibians of western India. Part 1. Journal of the Bombay Natural History Society 60: 415-438.

Daniel, J.C. (1963b). Field guide to the amphibians of western India. Parts 2. Journal of the Bombay Natural History Society 60: 690-702. Daniel, J.C. (1974). Amphibia. In: Kunte, B.G., Editor. Gazetteer of India, Maharashtra State Gazetteers, General Series: Fauna.
Government of Maharashtra.

Daniel, J.C. (1975). Field guide to the amphibians of western India. Part 3 in Journal of the Bombay Natural History Society 72: 506-522. Daniel, J.C. and A.G. Sekar (1989). Field guide to the amphibians of western India, Part 4. Journal of the Bombay Natural History Society 86: $194-203$.

Daniels, R.J.R. (1991). The problem of conserving amphibians in the Western Ghats, India. Current Science 60(11): 630-632.

Das, I. and S.K. Dutta (1998). Checklist of the amphibians of India with English common names. Hamadryad 23: 63-68.

Dasgupta, R. (1990). Distribution and conservation problems of the Himalayan Newt (Tylototriton verrucosus) in Darjeeling Himalayas. Hamadryad 15(1): 13-15.

Das, I. and S.K. Gupta (1998). Checklist of the amphibians of India with English common names. Hamadryad 23: 63-68.

Ghate, H.V. and A.D. Padhye (1988). Predation of Microhyla tadpoles by Gambusia. Journal of the Bombay Natural History Society 85: 200201.

Ghate, H.V. and A.D. Padhye (1996). Impact of urbanization on amphibians of Pune. Zoos' Print 11: 14-16.

Gupta, B.K. (1998). Declining Amphibians. Current Science 75: 8184.

Haulahan, J.E., C.S. Findlay, B.R. Schmidt, A.H. Meyer and S.L. Kuzmin (2000). Quantitative evidence for global amphibian population declines. Nature 404: 752-755.

Inger, R.F. (1996). Commentary on a proposed classification of the family Ranidae. Herpetologica 52(2): 241-246.

Lips, K.R. (1998). Decline of a tropical montane amphibian fauna. Conservation Biology 12(1): 106-117.

Matton, A. (2000). Amphibia Fading. World-Watch July/August 2000: 12-23.

Molur, S. and S. Walker (1998). Conservation assessment of the herpetofauna of India - an overview. Hamadryad 23(2): 169-178.

Padhye, A.D. and H.V. Ghate (2002). An overview of amphibian fauna of Maharashtra State. Zoos' Print Journal 17(3): 735-740.

Paranjape, S.Y. and L. Mulherkar (1979). On the survey of amphibian fauna in and around Pune. Journal of University of Poona, Science \& Technology 52: 423-434.

Ravichandran, M.S. and R.S. Pillai (1990). Amphibia of Maharashtra with description of a new species of Torrent Toad, Ansonia. Records of Zoological Survey of India 86: 505-513.

Sawant, S.B. (1972). The City of Poona: A Study in Urban Geography. Ph.D. Thesis. University of Poona.

Sekar, A.G. (1999). Four new records and checklist of amphibians from Maharashtra. Journal of the Bombay Natural History Society, 96(1): 152-157.

Shreshtha T.K. (1989). Ecological Aspects of the life history of the Himalayan Newt, Tylototriton verrucosus (Anderson) with reference to Conservation and Management. Journal of the Bombay Natural History Society 86(3): 333-338.

Vences, M., F. Glaw, J. Kosuch, I. Das and M. Veith (2000). Polyphyly of Tomopterna (Amphibia: Ranidae) based on sequences of the mitochondrial $16 \mathrm{~S}$ and $12 \mathrm{~S}$ rRNA genes, and ecological biogeography of Malagasy relict amphibian groups. Diversite et Endemisme a Madagascar 229-242.

Yazdani, G.M. and A. Mahabal (1976). Amphibians of Poona. Newsletter of the Zoological Survey of India 2: 138-139. 